JURNAL TERKNOSAINS

VOLUME 2

No. 2, 22 Juni 2013

Halaman 71-158

\title{
MANAJEMEN RISIKO TSUNAMI UNTUK PENATAAN RUANG DI PESISIR PERKOTAAN PACITAN JAWA TIMUR
}

\author{
Ratih Probosiwi \\ Balai Besar Penelitian dan Pengembangan Pelayanan Kesejahteraan Sosial (B2P3KS) \\ Yogyakarta- Kementerian Sosial R.I. \\ Email: ratih.probo@depsos.go.id \\ Sudibyakto \\ Fakultas Geografi Universitas Gadjah Mada
}

\begin{abstract}
The process of tsunami risk management through the use of disaster information is the important things to carry out by government of region with high potential tsunami hazard such as urban areas of Pacitan. Assessment of tsunami risk begins from hazard assessment, vulnerability and capacity assessment will provide appropriate information and also support decision making processes in order to reduce risk and loss that might arise when the disaster actually occurs. The policies of tsunami risk reduction could be done by spatial planning policy to regulate and control land usage in The Urban Pacitan. This article describes how the tsunami risk management for spatial planning done by the Pacitan Government.
\end{abstract}

Keywords: Tsunami Risk, Risk Management, Spatial planning, and The Urban Pacitan

\begin{abstract}
ABSTRAK
Proses pengelolaan risiko tsunami melalui penggunaan informasi kebencanaan merupakan hal yang penting dilakukan oleh pemerintah daerah dengan potensi bahaya tsunami yang tinggi seperti wilayah Perkotaan Pacitan. Penilaian risiko tsunami mulai dari penilaian bahaya, kerentanan dan kapasitas akan memberikan informasi yang tepat dan mendukung dalam proses perumusan kebijakan dalam rangka pengurangan risiko dan kerugian yang mungkin timbul bila bencana ini benar-benar terjadi. Kebijakan pengurangan risiko tsunami salah satunya melalui kebijakan penataan ruang untuk mengatur dan mengendalikan pemanfaatan ruang di Perkotaan Pacitan. Artikel ini mendeskripsikan bagaimana manajemen risiko tsunami untuk penataan ruang dilakukan oleh pemerintah Kabupaten Pacitan.
\end{abstract}

Kata Kunci: Risiko Tsunami, Manajemen Risiko, Penataan Ruang, dan Perkotaan Pacitan 


\section{PENGANTAR}

Indonesia yang terletak di zona "Ring of Fire" merupakan wilayah yang berpotensi untuk mengalami tsunami. Pacitan merupakan salah satu wilayah yang geografisnya berbatasan langsung dengan Pantai Selatan Jawa yang berpotensi mengalami tsunami. Pacitan berada di celah ketiga dari delapan celah seismik di seluruh Indonesia, juga sejajar dengan Cilacap, Yogyakarta, dan Trenggalek yang semakin meningkatkan potensi bahaya tsunami di wilayah ini (Diposaptono dalam republika. co.id, 2012). Bentuk teluk yang dimiliki pantai di pesisir Perkotaan Pacitan akan memperburuk risiko dan kerugian yang ditimbulkan bila wilayah ini terhantam gelombang tsunami (Mardiatno, 2008). Gambar 1 menunjukkan karakteristik Perkotaan Pacitan dengan bentuk teluk pada pantainya.

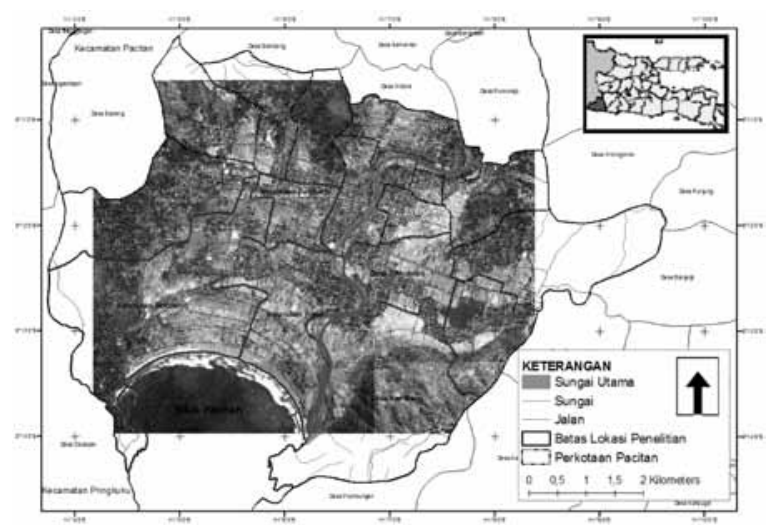

Gambar 1. Wilayah Perkotaan Pacitan dengan Teluk Pacitan

(Sumber: Pengolahan data, 2012, Citra Satelit Quickbird tahun 2006)

Tsunami merupakan bencana yang tidak dapat diprediksi kapan datangnya dan tak hanya merusak, bencana ini juga mampu menghancurkan apa saja yang dilaluinya. Secara bahasa, tsunami berasal dari kata tsu yang berarti pelabuhan dan nami yang berarti gelombang (Ilyas, 2006). Secara umum, tsunami diartikan sebagai gelombang besar yang menghantam daerah pesisir. Tsunami lebih banyak disebabkan adanya gempa besar di laut sebagai akibat patahan di dasar laut.

Bahaya tsunami yang berpotensi terjadi di Perkotaan Pacitan akan membawa banyak kerugian. Selain berdampak pada penduduk, tsunami juga berdampak pada penggunaan lahan, lingkungan, dan kegiatan sosial ekonomi di wilayah ini. Pada konsepsi penataan ruang, penilaian risiko tsunami tidak terlepas dari penilaian kerentanan sosial ekonomi penduduk. Jumlah kelompok rentan dan kelompok miskin di suatu wilayah akan mempengaruhi kemampuan wilayah tersebut dalam penanganan risiko bencana. Pengetahuan dan kesadaran penduduk akan informasi kebencanaan suatu upaya kesiagapan penduduk juga mempengaruhi penilaian risiko. Penggunaan lahan dan kaitannya dengan kegiatan perekonomian penduduk diatur dalam sistem penataan ruang wilayah. Sistem penataan ruang perlu memperhatikan informasi dan aspek kebencanaan di suatu daerah, ini sesuai dengan amanat UURI No. 24/2007 tentang Penanggulangan Bencana dan UURI No. 26/2007 tentang Penataan Ruang. Penting untuk dilakukan manajemen risiko guna penataan ruang sebagai salah bentuk upaya kesiapsiagaan dan mitigasi yang dapat dilakukan pemerintah daerah. Informasi kebencanaan yang ada di Kota Pacitan terutama bencana tsunami, perlu ditindaklanjuti melalui kegiatan pengelolaan informasi bahaya dan risiko bencana tsunami.

Tujuannya untuk mengetahui dan menganalisis upaya pemerintah dalam mengelola dan menggunakan informasi risiko tsunami di Pesisir Perkotaan Pacitan, kemudian dituangkan dalam kebijakan penataan ruang wilayah. Untuk mencapai tujuan tersebut, maka perlu menganalisis tingkat kerentanan sosial ekonomi, tingkat kapasitas (kesiapsiagaan masyarakat dan pemerintah) dalam menghadapi tsunami, tingkat risiko tsunami, dan akhirnya menganalisis kegiatan manajemen risiko 
tsunami untuk penataan ruang di Pesisir Perkotaan Pacitan.

Studikasusini dianalisis secara deskriptif evaluatif yaitu menganalisis kebijakan penataan ruang di Kabupaten Pacitan terutama di wilayah pesisir perkotaan. Teknik pengambilan sampel dilakukan secara purposif dengan pembatasan kuota sampel yang ditujukan untuk memperoleh informasi dan data yang tepat. Unit analisis penelitian dibatasi secara administratif yaitu unit analisis desa/kelurahan. Penelitian dilakukan melalui tiga tahap yaitu tahap persiapan, tahap survei lapangan serta tahap pengolahan, dan analisis.

Kajian ini dilakukan di Pesisir Perkotaan Pacitan dengan membatasi kegiatan analisisnya pada lima desa yang berpotensi terdampak tsunami dengan tingkat potensi "sangat tinggi" sesuai dengan penelitian yang dilakukan oleh Mardiatno tentang analisis zona berpotensi terdampak tsunami melalui skenario gempa 8,5 Mw. Dengan pembatasan tersebut, diperoleh lokasi penelitian yaitu Kelurahan Sidoharjo, Kelurahan Ploso, Desa Kembang, Desa Sirnoboyo, dan Kelurahan Baleharjo.

Pengumpulan data dimulai dari data sekunder melalui pencarian di situs internet, telaah dokumen penelitian terdahulu ataupun berita terkait manajemen risiko tsunami, dan penataan ruang. Pengumpulan data primer dilakukan melalui penyebaran kuesioner, survei instansi, wawancara, dan pelaksanaan focus group discussion (FGD). Kuesioner disebar kepada masyarakat pada lima desa lokasi penelitian sebanyak 150 kuesioner dengan masing-masing desa kurang lebih 30 kuesioner. Wawancara dilakukan di dinasdinas terkait manajemen risiko tsunami dan penataan ruang. FGD dilakukan untuk mengetahui proses manajemen risiko tsunami dari seluruh aspek pemerintahan (pemerintah, swasta, dan masyarakat).

Data yang dikumpulkan kemudian direkapitulasi berdasarkan jenis dan tujuannya untuk kemudian diolah dan dianalisis. Teknik yang digunakan terbagi menjadi dua yaitu teknik sistem informasi geografi dan teknik analisis deskriptif evaluatif. Teknik sistem informasi geografi dilakukan untuk pemetaan tingkat kerentanan, kapasitas, risiko, dan penataan ruang yang dilakukan melalui pembobotan dan overlay data.Kategoritingkat kerentanan, kapasitas, dan risiko dibagi menjadi lima kategori yaitu sangat tinggi, tinggi, sedang, rendah, dan sangat rendah. Hasil pemetaan kemudian dikaji secara deskriptif evaluatif.

\section{Tingkat Kerentanan Sosial-Ekonomi}

Tingkat kerentanan sosial ekonomi dinilai melalui parameter jumlah kelompok rentan (lansia, anak, dan balita; penyandang cacat; dan wanita hamil) danjumlah kelompok miskin (diperoleh melalui jumlah penerima BLT). Jumlah tiap parameter kemudian dikelaskan berdasarkan kurva normal dengan rumus yang ditunjukkan Tabel 1 .

Tabel 1. Pengkelasan Berdasarkan Kurva Normal

\begin{tabular}{llc}
\multicolumn{1}{c}{ Kategori } & \multicolumn{1}{c}{ Penghitungan Rentang Kelas } & Nilai \\
\hline Sangat Tinggi & $\mathrm{x}>=$ mean $+1.5 \mathrm{st.dev}$ & 5 \\
Tinggi & mean $+0.5 \mathrm{st.dev}<=\mathrm{x}<$ mean $+1.5 \mathrm{st.dev}$ & 4 \\
Sedang & mean $-0.5 \mathrm{st.dev}<=\mathrm{x}<$ mean $+0.5 \mathrm{st.dev}$ & 3 \\
Rendah & mean -1.5 st.dev $<=\mathrm{x}<$ mean -0.5 st.dev & 2 \\
Sangat Rendah & $\mathrm{x}<$ mean $-1.5 \mathrm{st.dev}$ & 1 \\
\hline
\end{tabular}

Peta kerentanan sosial ekonomi merupakan hasil overlay kedua parameter. Diagram penilaian kerentanan sosial ekonomi ditunjukkan pada Gambar 2. 


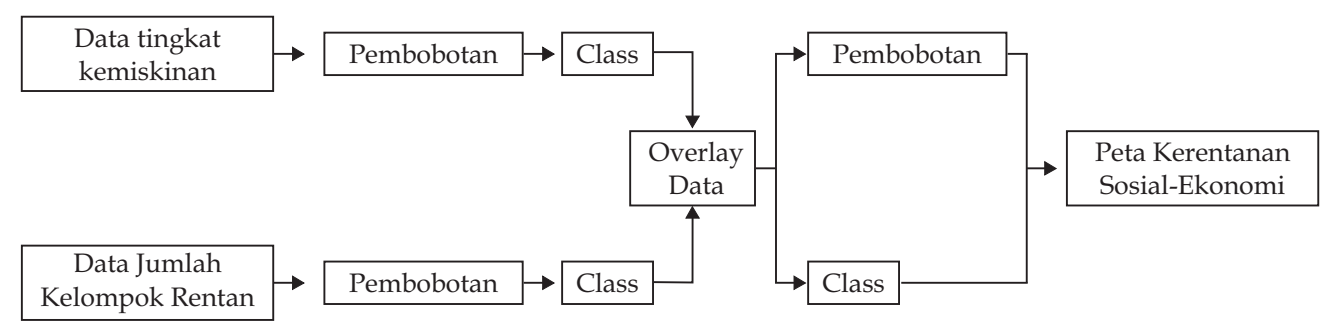

Gambar 2. Diagram Penilaian Kerentanan Sosial Ekonomi

\section{Tingkat Kapasitas}

Tingkat kapasitas Perkotaan Pacitan dinilai dengan indeks kesiapsiagaan individu dan rumah tangga Perkotaan Pacitan (IRT) serta indeks kesiapsiagaan Pemerintah Kabupaten Pacitan (P). Nilai indeks dihitung melalui beberapa parameter penilaian yaitu pengetahuan dan sikap (knowledge), rencana tanggap darurat (planning), peringatan bencana (warning), mobilisasi sumber daya (resource mobilization), kebijakan, dan panduan (policy and spatial planning). Formula yang digunakan dalam penghitungan indeks yaitu:

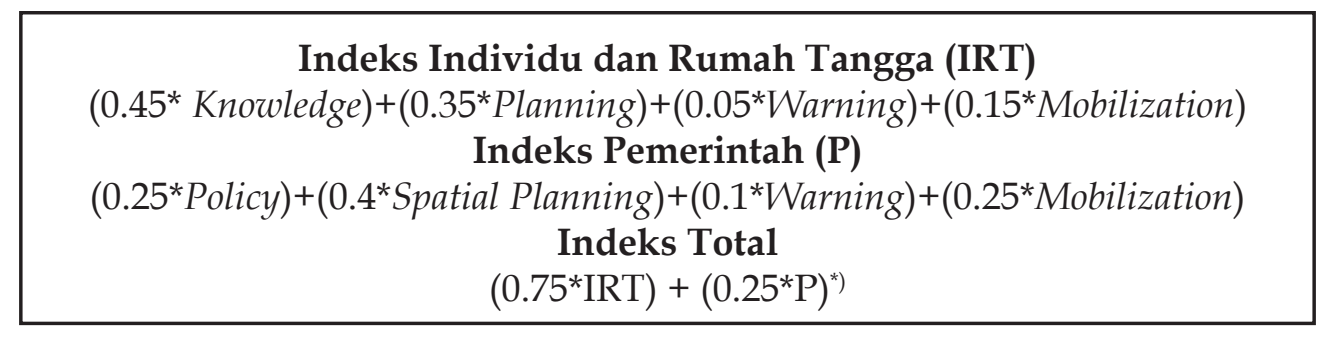

*) Pembobotan pada indeks total dilakukan melalui pairwise comparrison dengan pertimbangan bahwa indeks Individu dan Rumah Tangga diasumsikan sedikit lebih penting dibanding indeks Pemerintah (faktor indeks IRT terhadap P adalah 3, dan faktor indeks $P$ terhadap IRT adala 1/3).

Pengkelasan tingkat kapasitas dilakukan dengan Metode Sturges sebagai berikut:

Rentang Kelas $=\underline{\text { Nilai Tertinggi }- \text { Nilai Terendah }}$

$$
\text { Jumlah Kelas }
$$

\section{Tingkat Risiko Tsunami}

Penilaian risiko tsunami dilakukan dengan memperhatikan aspek kapasitas selain kerentanan dan bahaya sehingga rumus yang digunakan sebagai berikut:

Risiko $=($ Bahaya $\times$ Kerentanan $) /($ Kapasitas $)$

Penilaian tingkat risiko tsunami dilakukan sesuai Gambar 3.

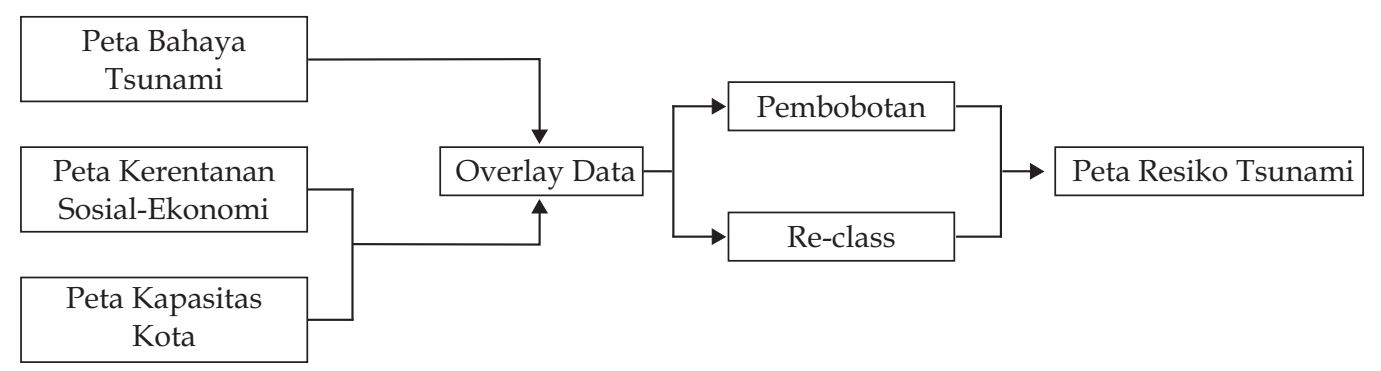

Gambar 3. Diagram Penilaian Tingkat Risiko Tsunami 


\section{MANAJEMEN RISIKO TSUNAMI UNTUK PENATAAN RUANG}

Analisis dilakukan secara dekriptif evaluatif untuk mengetahui kesesuaian antara informasi risiko tsunami dengan perencanaan pemanfaatan ruang wilayah Perkotaan Pacitan. Kesesuaian perencanaan pemanfaatan ruang dengan risiko tsunami dibagi menjadi empat criteria sebagai berikut:

Pertama, sesuai jika rencana pemanfaatan lahan telah sesuai dengan tingkat risiko tsunami. Dengan artian bahwa kawasan-kawasan strategis dengan pelibatan penduduk yang tinggi tidak sesuai bila dilokasikan di wilayah dengan tingkat risiko tinggi. Kedua, belum optimal jika rencana pemanfaatan lahan secara umum telah sesuai dengan risiko tsunami, tetapi penggunaannya dinilai belum optimal. Ketiga, review artinya jika rencana pemanfaatan lahan tidak sesuai dengan tingkat risiko yang ada, tetapi secara ekologis pemanfaatan lahan tersebut masih perlu/dapat dipertahankan. Keempat, Tidak sesuai jika rencana tidak sesuai dengan tingkat risiko tsunami dan dinilai kurang mampu mencerminkan proses pembangunan yang berkelanjutan.

Peta kesesuaian rencana tata ruang dengan risiko tsunami diperoleh melalui overlay peta risiko tsunami dan peta perencanaan pemanfaatan ruang seperti ditunjukkan pada Gambar 4. masyarakat lain dengan asumsi bila terjadi bahaya, maka kelompok ini akan lebih mudah terkena dampaknya dikarenakan keterbatasan kemampuan menyelamatkan hidup (Hoesin, 2003).

Data diperoleh melalui monografi dan profil desa/kelurahan. Data menunjukkan bahwa di antara kelima desa daerah tersebut, Kelurahan Sidoharjo memiliki jumlah kelompok rentan yang paling banyak yaitu sebesar 2576 jiwa yang mengkategorikan wilayah ini dengan kerentanan tinggi, disusul dengan Kelurahan Ploso sebanyak 2053 jiwa dengan kategori kerentanan tinggi, Desa Sirnoboyo sebanyak 1528 jiwa dengan kategori sedang, selanjutnya Kelurahan Baleharjo dan Desa Kembang dengan kategori kerentanan rendah dengan jumlah kelompok rentan masing-masing 1143 jiwa, dan 874 jiwa.

\section{Jumlah Kelompok Miskin}

Kelompok miskin dianggap rentan bila terkena bahaya dengan asumsi bahwa kelompok ini akan kesulitan untuk bangkit dan mengembalikan kehidupannya dalam kondisi yang lebih baik atau paling tidak sama seperti semula. Hal ini dikarenakan keterbatasan sumber daya selain keterbatasan akses yang dimilikinya. Menurut Bappenas (2004), kemiskinan merupakan kondisi di

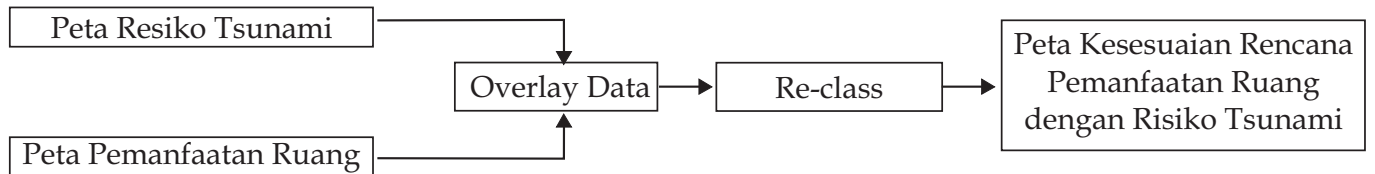

Gambar 4. Diagram Kesesuaian Pemanfaatan Ruang dengan Risiko Tsunami

\section{PEMBAHASAN}

\section{Kerentangan Sosial Ekonomi Pesisir Perkotaan Pacitan Jumlah Kelompok Rentan}

Kelompok rentan menurut UURI No. 24/2007 terdiri atas bayi, balita, dan anakanak; ibu hamil dan menyusui; penyandang cacat; dan orang lanjut usia. Kelompok ini dinilai lebih rentan daripada kelompok mana seseorang atau sekelompok orang tidak mampu memenuhi hak-hak dasarnya untuk mempertahankan dan mengembangkan kehidupan yang bermartabat. Jumlah kelompok miskin diperoleh melalui jumlah penerima BLT pada tahun 2009.

Pengkelasan kerentanan berdasarkan jumlah kelompok miskin menunjukkan tingkatan kerentanan pada kerentanan "tinggi" 
untuk Kelurahan Sidoharjo (jumlah kelompok miskin sebanyak 328 KK), kerentanan "sedang" untuk Kelurahan Ploso (sebanyak 212 KK) serta Desa Sirnoboyo (sebanyak 159 KK), dan kerentanan "rendah" untuk Desa Kembang (sebanyak 107 KK) serta Kelurahan Baleharjo (sebanyak 57 KK).

\section{Analisis Kerentanan Sosial Ekonomi}

Analisis dilakukan dengan overlay data kerentanan menurut jumlah kelompok rentan dan kelompok miskin. Penilaian kerentanan sosial ekonomi di lima desa/kelurahan lokasi penelitian ditunjukkan pada Tabel 2.

Tabel 2. Penilaian Kerentanan Sosial Ekonomi Pesisir Perkotaan Pacitan

\begin{tabular}{lllll}
\hline \multirow{2}{*}{ No } & \multirow{2}{*}{ Desa/Kelurahan } & \multicolumn{2}{c}{ Kerentanan } & \multirow{2}{*}{ Kerentanan Total } \\
\cline { 3 - 5 } & Sidoharjo & Tinggi & Tinggi & Tinggi \\
2 & Ploso & Tinggi & Sedang & Sedang \\
3 & Kembang & Rendah & Rendah & Rendah \\
4 & Sirnoboyo & Sedang & Sedang & Sedang \\
5 & Baleharjo & Rendah & Rendah & Rendah \\
\hline
\end{tabular}

Hasil analisis yang telah dilakukan, diketahui bahwa pada kelima desa/kelurahan wilayah penelitian, tingkat kerentanan sosial-ekonomi menunjukkan kategori yang antara rendah sampai tinggi. Tidak ada nilai ekstrim (sangat tinggi atau sangat rendah) pada tingkat kerentanan. Nilai kerentanan "tinggi" ditunjukkan pada Kelurahan Sidoharjo, nilai kerentanan "sedang" ditunjukkan pada Kelurahan Ploso dan Desa Sirnoboyo, sedangkan nilai kerentanan "rendah" pada Desa Kembang, dan Kelurahan Baleharjo.

\section{Kapasitas Pesisir Perkotaan Pacitan}

Menurut LIPI (2006), terdapat lima faktor yang dapat dijadikan parameter kajian kesiapsiagaan masyarakat terhadap bencana yaitu pengetahuan dan sikap terhadap bencana, kebijakan dan panduan, rencana tanggap darurat, sistem peringatan bencana, dan kemampuan mobilisasi sumber daya.

\section{Kesiapsiagaan Individu dan Rumah Tangga}

Indeks kesiapsiagaan desa lokasi penelitian pada kategori yang tinggi kecuali Kelurahan Sidoharjo dengan kategori sedang. Ini menunjukkan bahwa masyarakat Pesisir Perkotaan Pacitan telah memiliki kesadaran untuk memperhatikan informasi kebencanaan terutama tsunami di daerah tempat tinggal mereka. Tingkat pengetahuan dan perilaku serta baik dan cukup tinggi ditunjukkan oleh masyarakat, walaupun masih terdapat kekurangan dalam hal kemampuan mobilisasi sumber daya. Nilai indeks kesiapsiagaan individu dan rumah tangga masyarakat Pesisir Perkotaan Pacitan ditunjukkan pada Tabel 3.

Tabel 3. Indeks Kesiapsiagaan IRT (Berdasarkan Desa/Kelurahan)

\begin{tabular}{llccccc}
\hline \multirow{2}{*}{ Parameter } & \multicolumn{5}{c}{ Desa/Kelurahan } \\
\cline { 2 - 6 } & Sidoharjo & Ploso & Kembang & Sirnoboyo & Baleharjo \\
\hline Knowledge\&Attitude & 65 & 71 & 73 & 73 & 67 \\
Emergency Planning & 56 & 58 & 63 & 59 & 61 \\
Warning System & 47 & 56 & 53 & 47 & 53 \\
Resource Mobilization & 50 & 41 & 51 & 41 & 42 \\
\hline Indeks IRT & 59 & 61 & 65 & 62 & 61 \\
\hline \multicolumn{1}{c}{ Keterangan } & Sedang & Tinggi & Tinggi & Tinggi & Tinggi \\
\hline
\end{tabular}




\section{Kesiapsiagaan Pemerintah Kota Pacitan}

Indeks kesiapsiagaan pemerintah dihitung melalui parameter kebijakan dan panduan, penatan ruang, sistem peringatan dini, dan mobilisasi sumber daya. Indeks kesiapsiagaan Pemerintah Kabupaten Pacitan per-parameter ditunjukkan pada Tabel.4.

Tabel 4. Indeks Kesiapsiagaan Pemerintah Kabupaten Pacitan

\begin{tabular}{lll}
\multicolumn{1}{c}{ Parameter } & \multicolumn{1}{c}{ Indeks } & \multicolumn{1}{c}{ Keterangan } \\
\hline Policy & 67 & Tinggi \\
Spatial Planning & 49 & Sedang \\
Warning System & 58 & Sedang \\
Resources Mobility & 41 & Sedang \\
Indeks Pemerintah & 52 & Sedang \\
\hline
\end{tabular}

Tabel 4. menunjukkan bahwa indeks kesiapsiagaan pemerintah menunjukkan kategori yang sedang dengan parameter kebijakan yang tinggi. Hal ini menjelaskan bahwa pemerintah Kabupaten Pacitan telah cukup memiliki kesadaran dalam mempersiapkan dirinya untuk menghadapi bencana tsunami, tetapi masih harus ditingkatkan terutama dalam kemampuan mobilisasi sumber daya.

\section{Kesiapsiagaan Pesisir Perkotaan Pacitan}

Tingkat kesiapsiagaan pesisir Perkotaan Pacitan merupakan indeks gabungan dari nilai indeks kesiapsiagaan individu dan rumah tangga serta indeks kesiapsiagaan Pemerintah daerah Pacitan. Dari kelima desa/kelurahan wilayah penelitian, Desa Kembang menunjukkan nilai kesiapsiagaan "tinggi", berbeda dengan keempat desa/kelurahan lain yang hanya berada pada kategori "sedang". Desa Kembang merupakan desa percontohan tanggap siaga bencana (desa tangguh) dan telah banyak memperoleh sosialisasi mengenai bencana tsunami. Selain itu juga banyak menjadi lokasi penelitian mengenai bencana baik itu tsunami, gempa, ataupun banjir. Hal ini yang kemudian membuat nilai kesiapsiagaan masyarakat menjadi "tinggi". Hasil penghitungan indeks kesiapsiagaan pesisir Perkotaan Pacitan ditunjukkan Tabel 5.

Tabel 5. Indeks Kesiapsiagaan Pesisir Perkotaan Pacitan

\begin{tabular}{|c|c|c|c|c|c|}
\hline \multirow{2}{*}{ No } & \multirow{2}{*}{ Desa/Kelurahan } & \multicolumn{2}{|c|}{ Komponen } & \multirow{2}{*}{ Indeks Total") } & \multirow{2}{*}{ Keterangan } \\
\hline & & IRT & Pemerintah & & \\
\hline 1 & Sidoharjo & 59 & 52 & 57,25 & Sedang \\
\hline 2 & Ploso & 61 & 52 & 58,75 & Sedang \\
\hline 3 & Kembang & 65 & 52 & 61,75 & Tinggi \\
\hline 4 & Sirnoboyo & 62 & 52 & 59,50 & Sedang \\
\hline 5 & Baleharjo & 61 & 52 & 58,75 & Sedang \\
\hline 6 & Gabungan & 61 & 52 & 58,75 & Sedang \\
\hline
\end{tabular}

${ }^{*}$ Nilai indeks total dihitung berdasarkan rumus: Indeks total $=0,75$ *Indeks IRT + 0,25 * Indeks P

\section{Tingkat Risiko Tsunami}

Penilaian tingkat risiko dilakukan melalui overlay data kerawanan, kerentanan dan kapasitas masyarakat. Penilaian kerentanan dilakukan pada kelima desa/kelurahan wilayah penelitian karena tingkat kerawanan bahaya yang telah dilakukan tidak membatasi tingkat kerawanannya pada unit desa/kelurahan, maka ada bagian dari desa/kelurahan tersebut yang kemudian "tanpa risiko" tsunami. Tingkat risiko tsunami di Pesisir Perkotaan Pacitan ditunjukkan pada Tabel 6. dan Gambar 6. 
Tabel 6. Tingkat Risiko Tsunami Pesisir Perkotaan Pacitan

\begin{tabular}{|c|c|c|c|c|}
\hline No & Desa/Kelurahan & Kelas Risiko & Luas $\left(\mathrm{km}^{2}\right)$ & $\begin{array}{c}\text { Persentase (\%) } \\
\text { (dari Total Luas Wilayah) }\end{array}$ \\
\hline \multirow[t]{3}{*}{1} & Sidoharjo & Tinggi & 4,254 & 54,07 \\
\hline & & Sedang & 0,534 & 6,79 \\
\hline & & Rendah & 0,605 & 7,69 \\
\hline \multirow[t]{3}{*}{2} & Ploso & Sangat Tinggi & 3,623 & 87,77 \\
\hline & & Tinggi & 0,458 & 11,09 \\
\hline & & Sedang & 0,043 & 1,04 \\
\hline \multirow[t]{2}{*}{3} & Kembang & Sedang & 1,211 & 17,22 \\
\hline & & Rendah & 1,462 & 20,79 \\
\hline \multirow[t]{2}{*}{4} & Sirnoboyo & Sedang & 1,159 & 50,16 \\
\hline & & Rendah & 0,655 & 30,61 \\
\hline \multirow[t]{2}{*}{5} & Baleharjo & Sedang & 0,789 & 60,89 \\
\hline & & Rendah & 0,420 & 32,41 \\
\hline
\end{tabular}

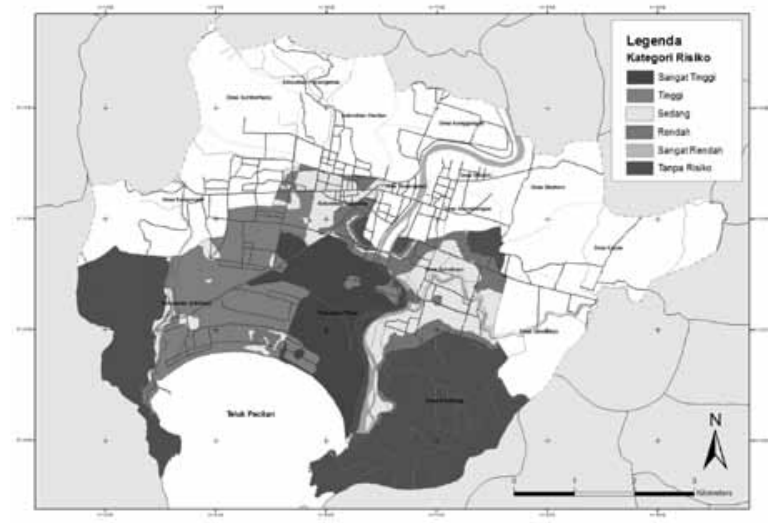

Gambar 6. Tingkat Risiko Tsunami di Pesisir Perkotaan Pacitan

Hasil analisis yang dilakukan di kelima desa/kelurahan wilayah penelitian menunjukkan bahwa sebagian besar wilayah Kelurahan Ploso berisiko "sangat tinggi" terhadap bencana tsunami yaitu seluas $3,623 \mathrm{~km}^{2}(87,77 \%$ dari wilayah keseluruhan Kelurahan Ploso). Sebagian kecil wilayah Kelurahan Ploso pada tingkat risiko "tinggi" dan "sedang". Wilayah Kelurahan Sidoharjo menunjukkan sebagian besar pada tingkat risiko "tinggi" (lebih dari 50\% luas total wilayah), sebagian lainnya menunjukkan tingkat risiko "sedang" dan sebagian lagi "tanpa risiko". Wilayah yang merupakan "tanpa risiko" merupakan daerah perbukitan yang mengelilingi teluk.
Kelurahan Baleharjo menunjukkan tingkat risiko yang bervariasi, tetapi sebagian besar berada pada tingkat risiko "sedang" (60\% dari luas total wilayah). Sebagian lain berisiko "rendah" dan "tanpa risiko". Walaupun kelurahan Baleharjo merupakan wilayah yang padat penduduk, tetapi jarak wilayah dari pantai yang relatif jauh $(>1500$ meter dari pantai) membuat wilayah ini relatif lebih aman dengan tingkat risiko "sedang".

Desa Sirnoboyo berada pada tingkat risiko "sedang" (lebih dari 50\% luas wilayah total) dan sisanya pada risiko "rendah". Terdapat pula beberapa wilayah yang "tanpa risiko" yang merupakan wilayah perbukitan dan menjadi tempat evakuasi bencana tsunami. Dari kelima desa/kelurahan penelitian, Desa Kembang berada pada tingkat risiko paling rendah (hanya kurang dari $30 \%$ wilayahnya yang terisiko tsunami).

\section{Penataan Ruang Perkotaan Pacitan}

Rencana penggunaan lahan di Perkotaan Pacitan, tentu tidak boleh bertentangan dengan pedoman dan strategi pengelolaan kawasan lindung dan budidaya. Terkait bencana ataupun secara ekonomi, kelangsungan kehidupan masyarakat, dan kelestarian lingkungan tetap harus diperhatikan. Rencana pemanfaatan pola 
ruang di Perkotaan Pacitan menurut RDTRK Pacitan ditunjukkan pada Gambar 7.

Secara umum pemanfaatan ruang di Perkotaan Pacitan masih rendah, hal ini dapat dilihat masih banyaknya lahan kosong. Pada perencanaan pemanfaatan ruang/ penggunaan lahannya, masih didominasi penggunaan lahan sebagai lahan cadangan dan kawasan budidaya (non-lindung). Hal ini perlu perhatian khusus agar tidak terjadi penetrasi lingkungan ke kawasan lindung dengan pertimbangan bahwa kawasan lindung merupakan perlindungan bagi kawasan sumber/mata air di daerah sekitarnya. Perlu perhatian agar tidak terjadi perubahan guna lahan kawasan lindung untuk menjaga keberadaan kawasan lindung.

Pada pembuatannya, RDTRK Pacitan tidak boleh menyimpang dari RTRW Kabupaten Pacitan. Berdasarkan rencana pemanfaatan lahannya terlihat bahwa RDTRK tetap mengacu pada ketentuan RTRW walaupun terdapatsedikit penyesuaian dengan kebutuhan dan kepentingan masyarakat yang telah ada dan memanfaatkan lahan tersebut. Perbandingan RDTRK Pacitan dengan RTRW Pacitan ditunjukkan pada Gambar 8.

Pelaksanaan penataan ruang, Kabupaten Pacitan menerapkan kegiatan pengendalian, dan pengawasan pemanfaatan ruang untuk menertibkan tata ruang melalui penentuan zonasi, ketentuan perizinan, insentif-disinsentif, arahan sanksi, serta kegiatan penertiban.

Kegiatan penertiban pernah dilakukan oleh Pemerintah Kabupaten Pacitan kepada masyarakat yang bermukim di sepanjang Sungai Grindulu. Relokasi dilakukan untuk memindahkan penduduk yang sebelumnya berada sangat dekat dengan sungai ke luar tanggul sungai sebagai upaya pengurangan risiko banjir di sepanjang Sungai Grindulu.

\section{Manajemen Risiko Tsunami untuk Penataan Ruang}

Di Perkotaan Pacitan, hampir seluruh wilayahnya merupakan wilayah rawan tsunami dengan tingkat kerawanan bervariasi
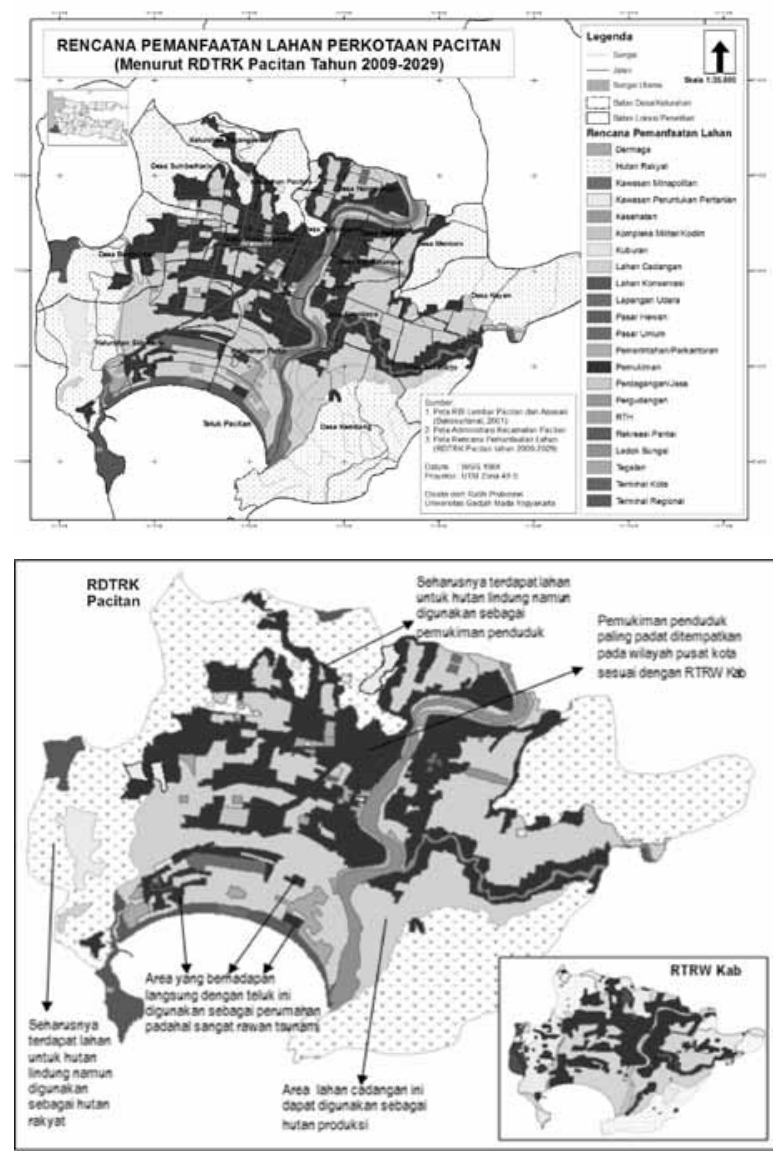

Gambar 8. Perbandingan RDTRK Pacitan Terhadap RTRW Kabupaten Pacitan

antara kerawanan "sangat rendah" sampai dengan dominasi pada tingkat kerawanan "sangat tinggi".

Tata kelola pemerintahan (governance) yang dikembangkan pemerintah Pacitan dalam pengelolaan risiko bencananya, berhubungan dengan dimensi politis, dan administratif. Dimensi politis governance berhubungan dengan proses pembuatan keputusan dalam formulasi kebijakan termasukperencanaan pengurangan bencana. Dimensi politis ini juga berhubungan dengan bagaimana pemerintah menjalin kerjasama dengan sektor swasta dan non-pemerintah untuk meningkatkan kualitas kebijakan yang dihasilkan. Sedangkan dimensi administratif berhubungan proses implementasi kebijakan dan kinerja organisasi baik di tingkat pusat maupun daerah. 
Kesesuaian penataan ruang dengan tingkat risiko tsunami penting dilakukan menginat wilayah Pacitan merupakan wilayah rawan tsunami. Dengan intensitas penggunaan lahan yang terkonsentrasi pada pusat kota dengan dominasi pemukiman padat penduduk semakin membuat wilayah ini berisiko atas bencana tsunami. Kebutuhan lahan yang meningkat ternyata tidak berbanding lurus dengan potensi dan luas lahan.

Berdasarkan hasil analisis yang dilakukan, terdapat beberapa penggunaan lahan sebagai pemukiman padat penduduk yang ditempatkan pada wilayah dengan tingkat risiko "sangat tinggi". Wilayah perumahan ASABRI Kelurahan Ploso, wilayah permukiman dusun Barehan Kelurahan Sidoharjo merupakan contoh penggunaan lahan permukiman di wilayah rawan tsunami sekaligus tinggi risiko. Hal ini tentu tidak sesuai dengan prinsip pengelolaan risiko tsunami. Dalam evaluasi kesesuaian rencana pemanfaatan lahan dengan tingkat risiko tsunami di wilayah tersebut, maka analisis kesesuaian digunakan seperti ditunjukkan pada Tabel 7 dan divisualisasikan pada Gambar 9.

Tabel 7. Kesesuaian Rencana Pemanfaatan Lahan dengan

Tingkat Risiko Tsunami di Pesisir Perkotaan Pacitan

\begin{tabular}{|c|c|c|}
\hline Tingkat Risiko & Rencana Pemanfaatan Lahan & Kriteria \\
\hline \multirow[t]{4}{*}{ Sangat Tinggi } & Lahan Cadangan & Sesuai \\
\hline & Permukiman & Tidak Sesuai \\
\hline & Rekreasi Pantai & Tidak Sesuai \\
\hline & Tegalan & Review \\
\hline \multirow{11}{*}{ Tinggi } & $\mathrm{RTH}$ & Sesuai \\
\hline & Lahan Cadangan & Sesuai \\
\hline & Tegalan & Sesuai \\
\hline & Rekreasi Pantai & Review \\
\hline & Lahan Konservasi & Sesuai \\
\hline & Kawasan Minapolitan & Review \\
\hline & Hutan Rakyat & Sesuai \\
\hline & Permukiman & Tidak Sesuai \\
\hline & Kawasan Militer & Tidak Sesuai \\
\hline & Kuburan/Makam & Sesuai \\
\hline & Lapangan Udara & Tidak Sesuai \\
\hline \multirow[t]{14}{*}{ Sedang } & RTH & Sesuai \\
\hline & Lahan Cadangan & Belum Optimal \\
\hline & Tegalan & Sesuai \\
\hline & Rekreasi Pantai & Review \\
\hline & Lahan Konservasi & Belum Optimal \\
\hline & Kesehatan & Sesuai \\
\hline & Kawasan Minapolitan & Review \\
\hline & Permukiman & Review \\
\hline & Kawasan Militer & Review \\
\hline & Kuburan/Makam & Sesuai \\
\hline & Pemerintahan/Perkantoran & Sesuai \\
\hline & Perdagangan/Jasa & Sesuai \\
\hline & Terminal & Sesuai \\
\hline & Pergudangan & Sesuai \\
\hline \multirow[t]{5}{*}{ Rendah } & RTH & Sesuai \\
\hline & Lahan Cadangan & Belum Optimal \\
\hline & Tegalan & Belum Optimal \\
\hline & Rekreasi Pantai & Sesuai \\
\hline & Hutan Rakyat & Belum Optimal \\
\hline
\end{tabular}




\begin{tabular}{|c|c|c|}
\hline Tingkat Risiko & Rencana Pemanfaatan Lahan & Kriteria \\
\hline & Kawasan Minapolitan & Sesuai \\
\hline & Permukiman & Sesuai \\
\hline & Pemerintahan/Perkantoran & Sesuai \\
\hline & Perdagangan/Jasa & Sesuai \\
\hline & Terminal Kota & Sesuai \\
\hline Tanpa Risiko & Semua jenis pemanfaatan lahan & Sesuai \\
\hline
\end{tabular}

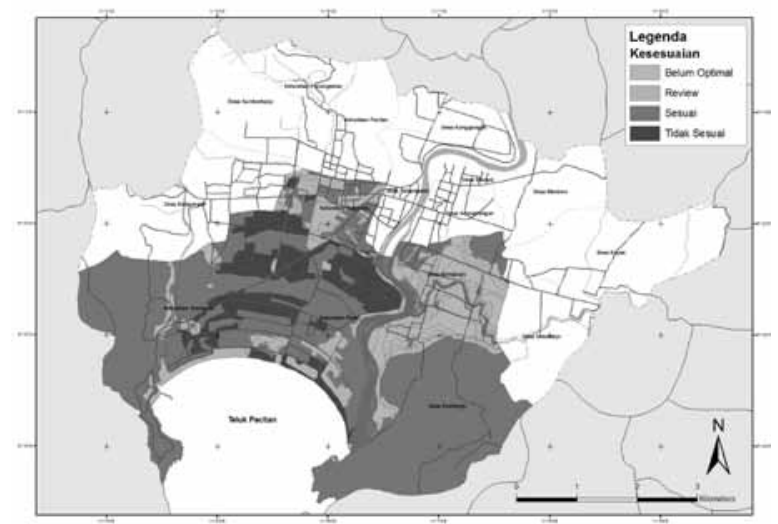

Gambar 9. Kesesuaian Rencana Pemanfaatan Lahan dengan Tingkat Risiko Tsunami di Pesisir Perkotaan Pacitan

Hasil dari analisis bahwa perencanaan pemanfaatan ruang di Perkotaan Pacitan kurang memperhatikan aspek risiko kebencanaan terutama pada pemanfaatan kawasan permukiman. Dari 292,80 Ha luas area yang tidak sesuai 239.96 Ha merupakan area permukiman atau lebih dari 90\% dari keseluruhan luas area tidak sesuai.

Jika diperhatikan dengan cermat, Perkotaan Pacitan merupakan wilayah dengan jumlah lahan cadangan cukup tinggi. Lahan cadangan ini pada kenyataannya digunakan sebagai lahan pertanian berupa sawah irigasi oleh penduduk Perkotaan Pacitan. Saat ini mulai menunjukkan gejala penetrasi kawasan permukiman di lahan cadangan yang ada, ini tentu tidak sesuai dengan perencanaan pemanfaatan lahan sekaligus juga tidak sesuai dengan tingkat risiko yang ada di wilayah lahan cadangan tersebut. Diperlukan tindakan tegas dari pemerintah untuk mengelola risiko dalam pemanfaatan ruangnya.

Menurut Asian Institute of Technology dan Doley dalam Widiati (2008), manajemen risiko tsunami secara umum dapat dilakukan melalui beberapa cara yaitu pengaturan ruang, sistem informasi dan keteknikan, pendidikan dan pemberdayaan masyarakat, dan kelembagaan. Pelaksanaannya di Pacitan sebagai berikut:

\section{Pemanfaatan ruang (spasial)}

Pemanfaatan ruang dilakukan oleh pemerintah kabupaten Pacitan dengan menyediakan zona buffer untuk mengurangi gelombang tsunami dan mengurangi daya rusaknya. Zona buffering yang telah dilakukan pemerintah adalah dengan menanam cemara laut sebagai pengganti mangrove. Akan tetapi, di belakang buffer zone tersebut digunakan sebagai lahan kosong dan diikuti dengan permukiman pada penduduk (berjarak kurang lebih 600 meter dari buffer zone). Kawasan pesisir Pantai Teleng digunakan sebagai sabuk hijau Perkotaan Pacitan dimulai sejak tahun 2008 dengan luas $9000 \mathrm{~m}^{2}$ yang dari tahun ke tahun luasnya terus meningkat. Selain itu juga di sepanjang sempadan Sungai Grindulu dibangun tanggul alami dan buatan setinggi kurang lebih 2 meter sebagai penahan banjir yang mungkin terjadi akibat aliran gelombang tsunami karena keberadaan sungai menjadi saluran yang baik untuk menyalurkan gelombang tsunami. 

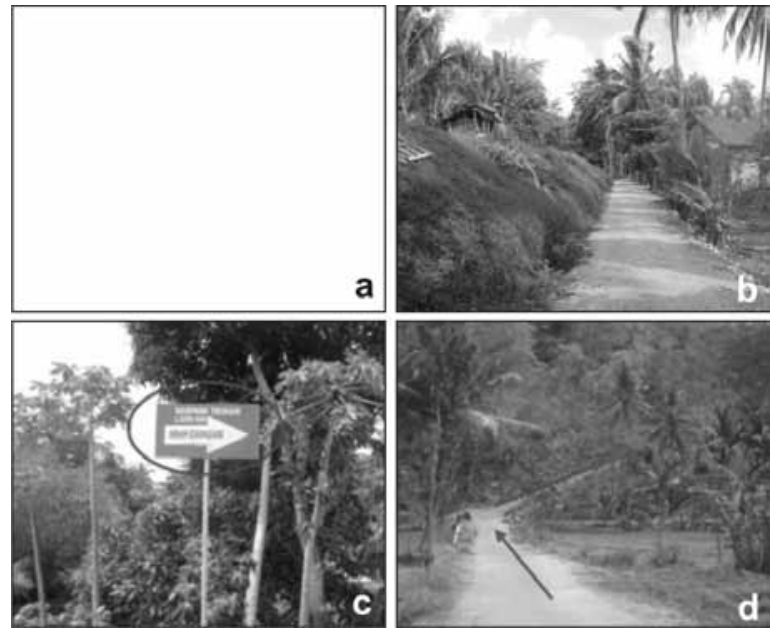

Gambar 10. Bentuk Pemanfaatan Ruang berbasis Risiko Tsunami di Pesisir Perkotaan Pacitan

Keterangan:

a. Greenbelt berupa cemara laut yang telah mencapai tinggi kurang lebih 5 meter, Kel. Ploso, 25 Januari 2012

b. Tanggul sungai Grindulu setinggi kurang lebih 2 meter, Kel. Ploso, November 2011.

c. Rambu jalur evakuasi tsunami, lokasi Desa Kembang, 9 Oktober 2011.

d. Arah evakuasi di Desa Kembang, 9 Oktober 2011.

\section{Keteknikan}

Di Pacitan telah dibangun rumah percontohan tahan gempa dan tsunami oleh Dinas Kelautan dan Perikanan pada tahun 2008. Awalnya, rumah ini merupakan rumah dua lantai dengan membiarkan kosong lantai satu sebagai saluran mengalirnya air apabila terjadi tsunami, tetapi perkembangannya, lantai satu ditutup dengan tembok dan difungsikan sebagai ruang tersendiri. Selain itu juga dilakukan melalui pengembangan sistem peringatan dini yang merupakan proyek kerjasama dengan BMKG dan juga adanya alat pendeteksi pasang surut air laut.

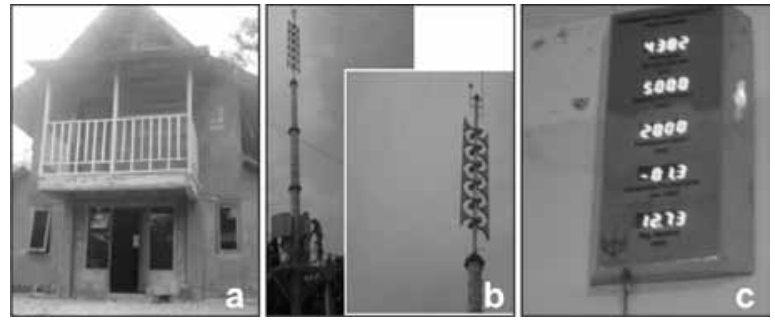

Gambar 11. Bentuk Keteknikan dalam Manajemen Risiko untuk Penataan Ruang di Pesisir Perkotaan Pacitan

Keterangan:

a. Rumah tahan gempa tsunami, lokasi Desa Kembang, 10 Oktober 2011

b. Tower InaTEWS, lokasi Kelurahan Ploso, 9 Oktober 2011

c. Detektor pasang surut air laut Teluk Pacitan, Kantor BPBD Pacitan, 25 Januari 2012

\section{Peningkatan pendidikan dan pemberdayaan masyarakat}

Pemerintah Pacitan telah melakukan kegiatan peningkatan pendidikan dan pemberdayaan masyarakat melalui kegiatan sosialisasi, rencana kontijensi, gladi lapang dan gladi posko, penyiapan desa tangguh, dan masyarakat peduli bencana.
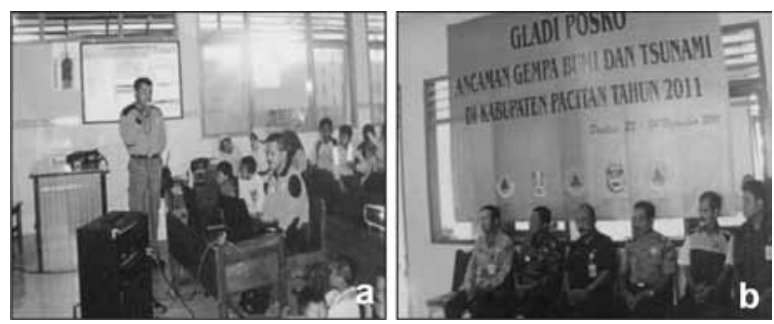

Gambar 12. Bentuk Peningkatan Pendidikan dan Pemberdayaan Masyarakat di Kabupaten Pacitan

(Sumber: Profil BPBD Pacitan, 2011)

\section{Keterangan:}

a. Sosialisasi kebencanaan di sekolah di Pacitan oleh BPBD Pacitan.

b. Gladi posko bencana gempabumi dan tsunami di Pacitan oleh BPBD Pacitan 


\section{Kelembagaan}

Pada kelembagaan, Pemerintah Pacitan telah memiliki Badan Penanggulangan Bencana Daerah (BPBD) sebagai organisasi pelaksana penanggulangan bencana. Organisasi ini telah memiliki struktur dan fungsi yang jelas, tetapi organisasi ini belum lama berdiri, masih banyak terdapat keterbatasan dalam sumberdaya manusia, pembiayaan, dan perlengkapan. Bentuk kelembagaan dalam manajemen risiko yaitu adanya rencana kontijensi yang dilakukan oleh Pemerintah Kabupaten Pacitan untuk merumuskan kegiatan kesiapsiagaan bencana yang diikuti oleh dinas pemerintahan terkait.

\section{Mitigasi Risiko Tsunami di Pesisir Perkotaan Pacitan}

Tindakan mitigasi dilakukan dengan penanaman vegetasi sebagai penyerap energi gelombang tsunami. Upaya penanaman vegetasi ini telah dilakukan di Pacitan seperti di pantai sebelah timur Teluk Pacitan. Vegetasi yang ditanam berupa cemara udang, pohon waru, dan ketapang. Penanaman vegetasi ini telah berlangsung sejak tahun 2008 berlanjut hingga sekarang dan terus memperluas area penanaman. Selain penanaman vegetasi sebagai barrier alami, pembangunan sistem evakuasi yang baik meliputi jalur evakuasi, kondisi jalan dan sistem transportasi evakuasi, serta pembangunan shelter pengungsian penduduk yang mudah dijangkau juga merupakan upaya mitigasi yang penting dilakukan. Lokasi evakuasi dapat diarahkan ke bukit terdekat atau melalui pembangunan sistem evakuasi vertikal misal masjid, sekolah, ataupun perkantoran di wilayah-wilayah kerawanan bahaya tsunami sedang atau rendah. Selain itu, perlu pula dikembangkan titik-titik perkumpulan evakuasi sementara untuk kemudian diangkut menuju lokasi evakuasi lain melalui sistem angkutan massal untuk menghindari kemacetan jika penduduk menggunakan kendaraan pribadi masing-masing.

Perencanaan pemanfaatan ruang sebagai upaya mitigasi juga dapat dilakukan melalui beberapa skenario misalnya memindahkan arahan fungsi tata ruang dari budidaya permukiman (sebagai fungsi yang memiliki luas ketidaksesuaian paling tinggi) ke area dengan tingkat risiko rendah dan sedang. Skenario lain yang dapat dilakukan adalah dengan perencanaan pengembangan konsentrasi pemukiman ke area dengan tingkat risiko rendah dan sedang. Pengaturan pemukiman dan fasilitas vital di kawasan risiko rendah dan sedang lebih masuk akal dilakukan untuk jangka panjang.

Proyeksi penambahan pemukiman di titik lokasi risiko sedang dan rendah juga dapat dilakukan karena melihat potensi Perkotaan Pacitan yang masih mampu untuk dikembangkan. Jumlah lahan cadangan yang banyak dapat dioptimalkan sebagai pengembangan pemukiman baru dan fasilitas vital dengan tetap memperhatikan aspek risiko bencana. Melalui proyeksi jumlah pertambahan penduduk dari tahun ke tahun, pemerintah dapat melakukan perencanaan pengembangan permukiman ini.

Arahan pengembangan pemukiman dapat dilakukan di wilayah Sedeng, Bangunsari, Sumberharjo, Pucangsewu, Pacitan, Widoro, atau Nanggungan yang masih memiliki banyak lahan kosong. Secara geografis, wilayah ini berada jauh dari pantai dan memiliki topografi yang lebih tinggi sehingga relatif lebih aman dari bahaya tsunami. Perencanaan tata ruang tidak hanya dilakukan melalui pengaturan pemukiman, tetapi pengaturan fasilitas vital lain seperti pelayanan komersial, komunikasi, listrik, sistem gas alam, pelayanan darurat, dan air.

\section{SIMPULAN}

Kebijakan rencana pemanfaatan ruang di Perkotaan Pacitan kaitannya dengan tingkat risiko tsunami, maka pemerintah belum terlalu memperhatikan aspek risiko kebencanaan. Terbukti dengan terdapat beberapa penggunaan lahan sebagai pemukiman padat penduduk yang ditempatkan pada wilayah dengan tingkat risiko "sangat tinggi". 
Informasi risiko tsunami belum digunakan dalam penataan ruang dengan munculnya kategori "tidak sesuai" terutama pada penggunaan lahan pemukiman.

Pengelolaan risiko tsunami adalah tanggung jawab bersama baik itu oleh pemerintah, pihakswastamaupunmasyarakat. Pemahaman akan tanggung jawab masingmasing dan kesediaan untuk bekerjasama dan pelibatan semua aktor menjadi hal penting untuk benar-benar dilakukan sebagai berikut: Pertama, diperlukan peningkatan kapasitas masyarakat dan juga pemerintah untuk mengurangi risiko tsunami sebagai tindakan preparedness atas kemungkinan bencana dan peningkatan kerjasama antara pemerintah, swasta, dan masyarakat dalam penanganan risiko tsunami.

Kedua, diperlukan review atas perencanaan pemanfaatan ruang yang telah ada di beberapa kawasan yang tidak sesuai dengan risiko tsunami dan aspek-aspek kebencanaan tsunami lainnya. Pengembangan titik konsentrasi pemukiman baru di lokasi berisiko sedang atau rendah dapat dilakukan untuk mengurangi risiko tsunami. Optimalisasi pemanfaatan lahan cadangan sebagai kawasan penyangga kawasan permukiman, selain juga pembangunan titik evakuasi vertikal dan horisontal serta pembangunan sistem jaringan transportasi yang memperlancar proses evakuasi.

\section{DAFTAR PUSTAKA}

Bappenas, 2004, Strategi Nasional Penanggulangan Kemiskinan: Draft Sementara, Jakarta: Bappenas.

Dinas Cipta Karya Pacitan, 2009, Laporan Final Revisi Rencana Detail Tata Ruang Kota Pacitan Tahun 20092029, Pacitan: Dinas Cipta Karya Pacitan.

Hoesin, Iskandar, 2003, Perlindungan Terhadap Kelompok Rentan dalam Perspektif Hak Asasi Manusia, Seminar Pembangungan Hukum Nasionalke VIII Tahun 2003, Denpasar.
IIlyas, T, 2006, Mitigasi Gempa dan Tsunami di Daerah Perkotaan, Seminar Bidang Kerekayasaan Fatek-Unsrat, Manado: Universitas Sam Ratulangi.

LIPI, 2006, Kajian Kesiapsiagaan Masyarakat dalam Mengantisipasi Bencana Gempa Bumi \& Tsunami di Indonesia, Jakarta: LIPI-UNESCO/ISDR.

Mardiatno, Djati, 2008, Tsunami Risk Assessment Using Scenario-Based Approach, Geomorphological Analysis and Geographic Information System: A Case Study in South Coastal Areas of Java IslandIndonesia, Disertasi (Dr), Innsbruck: Faculty of Geo-and Atmospheric Sciences University of Innsbruck.

Perda Kabupaten Pacitan No. 3 tahun 2010 tentang Rencana Tata Ruang Wilayah Kabupaten Pacitan 200920028

Republika, 2012, Ada Delapan Celah Seismik Rawan Tsunami, Jakarta. http:/ / id.berita.yahoo.com/adadelapan-celah-seismik-rawantsunami-140100193.html, diakses tanggal 30 Januari 2012.

UURI No. 24 tahun 2007 tentang Penanggulangan Bencana, Lembaran Negara 2007 Nomor 66, Tambahan Lembaran Negara Republik Indonesia Nomor 4723

UURI No. 26 tahun 2007 tentang Penataan Ruang, Lembaran Negara Republik Indonesia Tahun 2007 Nomor 68, Tambahan Lembaran Negara Republik Indonesia Nomor 4725

Widiati, Ati, 2008, Aplikasi Manajemen Risiko Bencana Alam dalam Penataan Ruang Kabupaten Nabire, Jurnal Sains dan Teknologi Indonesia Vol. 10 No. 1 April 2008 hal. 7-15, Jakarta: Pusat Pengkajian Kebijakan Peningkatan Daya Saing, BPPT. 